\title{
Comparison of two different dry-needling techniques in the treatment of myofascial pain syndrome
}

\author{
İki farklı kuru iğneleme tekniğinin miyofasial ağrı sendromunun tedavisinde karşılaştırılması
}

\author{
Özlem TAŞOĞLU,' Şule ŞAHIN ONAT,' Hüma BÖLÜK, 'i Irfan TAŞOĞLU, ${ }^{2}$ Neşe ÖZGiRGiN' ${ }^{1}$
}

\begin{abstract}
Summary
Objectives: To compare the efficacy of two different dry needling (DN) techniques (deep dry needling \& peppering) in myofascial pain syndrome (MPS).

Methods: Seventy-two patients, who were diagnosed as MPS at our outpatient clinic were randomly assigned into two groups as deep dry needling (DDN) and peppering. All patients were evaluated four times as: before the treatment and 1-5-12 weeks after the completion of treatment protocol. In each evaluation, Visual analogue scale (VAS), Nottingham extended activities of daily living scale (NEADLS), Beck depression inventory (BDI) scores were recorded. Additionally, all patients were evaluated for the pain felt during the procedure and side effect profile.

Results: Twenty-six patients from DDN group and twenty-eight patients from peppering group accomplished the follow-up period. Both DDN and peppering seem to be effective for relieving pain and depressive symptoms and improving functionality compared to baseline when evaluated on the $1^{\text {st }}, 5^{\text {th }}$ and $12^{\text {th }}$ weeks. On the other hand the intergroup analyses showed no significant differences between DDN and peppering groups. The only significant difference between the groups is the lesser pain felt during the procedure in the DDN group.
\end{abstract}

Conclusion: Both DDN and peppering are effective in MPS and the effects last up to 12 weeks. Also the adverse event profiles of the two techniques are similar. On the other hand, DDN is a painless procedure.

Keywords: Deep dry needling; dry needling; myofascial pain syndrome; peppering.

\section{Özet}

Amaç: Çalışmanın amacı iki farklı kuru iğneleme yönteminin (derin kuru iğneleme ve peppering) miyofasial ağrı sendromunda (MAS) karşılaştırılması.

Gereç ve Yöntem: Hastanemize başvuran MAS tanısı alan 72 hasta, rasgele derin kuru iğneleme ve peppering olmak üzere iki gruba ayrıldı. Tüm hastalar 4 kez değerlendirildi; tedaviden önce ve tedavide uygulamasından sonraki 1.-5. ve 12. haftalarda. Her değerlendirmede hastalara Vizüel Analog Skala, Nottingham Genişletilmiş Günlük Yaşam Aktiviteleri Skalası ve Beck Depresyon Ölçeği uygulandı. Ek olarak hastalar prosedür boyunca ağıı hissi ve yan etki profili açısından takip edildi.

Bulgular: Takip sürecini 26 derin kuru iğneleme ve 28 peppering hastası tamamladı. Başlangıca göre bakıldığında her iki grupta da 1.-5. ve 12. hafta kontrollerinde ağıının azaltılması, depresif semptomları ve fonksiyonelliğin artırlması açısından fayda sağlandı. Öte yandan gruplararası analizlerde her iki grup arasında anlamlı fark saptanmadı. Her iki grup arasındaki tek anlamlı farklılık uygulama sırasında derin kuru iğneleme grubunda ağrının daha az olmasıydı.

Sonuç: Derin kuru iğneleme de peppering de MAS tedavisinde etkili ve bu etki 12 haftaya kadar devam etmektedir. Ayrıca her iki tekniğin de yan etki profili benzer saptandı. Öte taraftan, derin kuru iğnelemenin daha ağrısız bir prosedür olduğu görüldü.

Anahtar sözcükler: Derin kuru iğneleme; kuru iğneleme; myofasial ağrı sendromu; peppering.

\section{Introduction}

MPS (myofascial pain syndrome) is a common painful condition characterized by localized thigt knotty areas, known as trigger points (TP) in the muscles which are usually extremely tender to palpation. Pain may refer to a distant area and may be accompanied by sensory disturbances (paresthesia, dysesthesia) and/or autonomic phenomena (piloerec-

\footnotetext{
'Department of Physical Medicine and Rehabilitation, Ankara Physcial Medicine and Rehabiliation Training and Research Hospital, Ankara, Turkey 2Physical Medicine and Rehabilitation, Ankara Yüksek İhtisas Training and Research Hospital, Ankara, Turkey

Submitted (Başvuru tarihi) 07.02.2016 Accepted after revision (Düzeltme sonrası kabul tarihi) 29.09.2016 Available online date (Online yayımlanma tarihi) 26.12.2016

Correspondence: Dr. Hüma Bölük. Ankara Fizik Tedavi ve Rehabilitasyon Eğitim ve Araştırma Hastanesi, Hacettepe Mahallesi, Türkocağı Sokak, No: 3, 06230 Altındağ, Ankara, Turkey. Phone: +90 - 312 - 3103230 e-mail: humaboluk@gmail.com

C) 2017 Turkish Society of Algology
} 
tion, sweating). ${ }^{[1]}$ TP may be active or latent. Active TP cause spontaneous pain and may lead to satellite TP formation whereas latent ones are asymptomatic unless palpated firmly. ${ }^{[2]}$ Latent TP can develop into active ones as a result of psychological stress, poor posture, sudden injury, muscle overload, repetitive microtrauma. ${ }^{[3]}$

MPS can cause significant reduction in quality of life (QOL) and is a major cause of time lost from work. There is no racial or gender differences in the incidence of MPS, and also it can be seen in all age groups even in infants with an increasing prevalance in the middle aged, the most productive era. ${ }^{[4]}$ It may be accompanied by many functional and psychiatric complications such as anxiety, depression and loss of functional capacity as well. ${ }^{[5]}$

Dry needling is effectively used in the treatment of MPS. In the literature, the term 'dry-needling' accounts for both the use of solid filiform acupuncture needles and hollow-core hypodermic needles. Altough they seem similar, they originate from two different theories. The technique in which acupuncture needles are used is first described by Gunn. ${ }^{[6]}$ It is derived from traditional Chineese acupuncture and referred as intramuscular stimulation, Western acupuncture or medical acupuncture too. Several approaches emerged emprically in time, one of them coming forward: deep dry needling (DDN). In DDN, the acupuncture needle is inserted into the skin and the muscle targeting the trigger point inside the taut band. There are a number of studies in the literature demonstrating its efficacy. ${ }^{[7-9]}$ The other technique that uses hypodermic needles is first described by Travell and Simons in 1942 on the other hand. ${ }^{[10]}$ First they preferred $22 \mathrm{G}, 1.5$ in needles, suitable for most superficial muscles for local anesthesic injections. In 1979 Lewitt and then in 1994 Hong proposed that the effect of pain relief is primarily due to the mechanical stimulation of the muscle tissue not the local anesthesic. ${ }^{[11,12]}$ Since then, injections without local anesthesics got popularity and lots of clinical trials proved its efficacy in MPS. ${ }^{[5,13]}$ But to the best of our knowledge there isn't a literature in which hypodermic needles are compared with acupuncture needles for the dry needling of myofascial trigger points..$^{[3]}$

So the principal goal of this study was to assess the difference between the two main dry needling techniques and compare their efficacy with each other in the means of pain, depression and activities of daily living in the short, medium and late term follow-up. The adverse event profiles were also evaluated.

\section{Materials and Methods}

\section{Study design}

The study was designed as a prospective, randomized trial in which two different dry-needling techniques are compared. The study protocol is compatible with Helsinki declaration and approved by Hospital Ethics Committee. Written and oral informed consents were obtained from the participants before allocation.

\section{Participants and randomization}

Seventy-two subjects with MPS were included into the study between December 2013 and May 2014 in a specialty referral center. The MPS diagnosis was made clinically according to Travell and Simons' criteria. There are 5 major and 3 minor diagnostic criteria which were defined by Travell and Simons. Major criteria were; 1 . localized spontaneous pain, 2. spontaneous pain/altered sensation in a defined referred pain area for trigger points, 3. taut, palpable bands in muscles, 4. exquisite tenderness along the taut bands, 5 . a measurable degree of loss in range of motion. Minor criteria were; 1 . reproduction of pain and altered sensations by palpating the taut bands, 2. obtaining a local twitch response by transverse snapping palpation or needle insertion into the taut bands, 3. pain relief after stretching or injection of the taut bands. Five major and at least 1 minor criteria are needed for MPS diagnosis ${ }^{[10]}$ Pretreatment workup included complete blood count, erythrocyte sedimentation rate, starving blood glucose and hepatic and renal function tests. Participants with concomittant fibromyalgia, thoracic outlet syndrome, cervical radiculopathy, cervical spondyloarthropathy, shoulder disorders, rheumatological or malign diseases were excluded. Each patient who met these criteria was then randomized by pulling a sealed envelope containing the information about the needling technique.

\section{Interventions}

\section{Deep dry needling (DDN) technique}

While the patient was sitting, the sterile acupuncture needles of $0.25 \times 40 \mathrm{~mm}$ (Hua Long) were inserted 
into the skin over the palpated trigger points and forwarded deeply into the taut bands. Reproduction of pain or local twitch response is accepted as appropriate needle location. Needles were left in situ for 10 minutes, rotated clockwise at the $10^{\text {th }}$ minute, and then left in situ for another 10 minutes. After a total of 20 minutes the needles were taken off. ${ }^{[14]}$

\section{Peppering technique}

While the patient was sitting, the sterile $22 \mathrm{G}$ needles $32 \mathrm{~mm}$ in length were inserted into the taut bands. ${ }^{[13]}$ The trigger points were needled by moving the needle forward and backward 8-10 times at the same point, rotated clockwise and then by changing the inclination angle of the needle surrounding muscular tissue were also needled. Reproduction of pain or local twitch response is accepted as appropriate needle location. This technique, introduced by Travell in $1942,{ }^{[10]}$ is entitled as peppering in this paper to prevent misunderstanding.

Both treatment protocols were composed of three sessions performed on the same day of each week for three weeks (Figure 1). A home based exercise program composed of streching of trapezius and isometric strengthening of neck muscles were described and the participants were not allowed to take non steroidal anti-inflamatory medications and myorelaxants.

\section{Assesments}

All the patients were evaluated four times as: before the treatment protocol, 1 week after the completion of treatment protocol, 5 weeks after the completion of treatment protocol and 12 weeks after the completion of treatment protocol. In each evaluation, daytime and night pain were evaluated by Visual analogue scale (VAS), activities of daily living (ADL) were assesed by Nottingham extended activities of daily living scale (NEADLS) and depression and anxiety were evaluated with Beck depression inventory (BDI) (Figure 1). In addition to these, all patients were evaluated in the first treatment session for the pain felt during the procedure and after the last session for the side effects they have experienced.

\section{VAS}

Daytime and night pain were evaluated by using VAS, a $10 \mathrm{~cm}$ horizontal line, where the endpoints
0 and 10 indicated no pain and worst possible pain respectively. VAS was also used for assesing the pain felt during the procedure.

\section{NEADLS}

Originally developed for stroke patients, NEADLS is started to be used in a variety of clinical conditions icluding some musculoskeletal disorders. It consists of 4 subsections as mobility ( 6 items), kitchen (5 items), domestic (5 items) and leisure time activities (6 items). The answers of each question has a rank between 0 and 3 points. The sum of the rank values of 22 items range between 0 and 66 points, meaning 0 -worst and 66-best value in daily activities. The Turkish validity and reliability was performed by Sahin et al. ${ }^{[15]}$

\section{BDI}

$\mathrm{BDI}$ is a 21-item self-report measure assessing affective, cognitive, and somatic symptoms of depression. All 21 items have 4 different options with a score ranging between 0 and 3, 0 meaning the least and 3 meaning the most depressive status. Patients are asked to choose one of the alternative sentences which most fits their situation in the last 2 weeks. The total score is between 0 and 63 . Higher total scores indicate more severe depressive symptoms. The Turkish validity and reliability of BDI was performed by Hisli et al. ${ }^{[16]} \mathrm{BDI}$ is used to assess mood in MPS. ${ }^{[13]}$

\section{Statistical analysis}

Continuous variables are given as the median $\pm S D$, categorical variables are defined as percentages. To compare continuous variables, the student t-test or Mann-Whitney $U$ test are used where appropriate. Statistical significance is defined as $p<0.05$. The SPSS for Windows statistical software (SPSS Inc, Chicago, IL, USA) was used for all statistical calculations.

\section{Results}

A total of 72 patients were randomized into deep dry needling $(n=36)$ and peppering $(n=36)$ groups. 10 patients from DDN and 8 patients from peppering groups have dropped out of the study at different times according to several reasons described in the flow-chart of the study and finally 26 patients from DDN group and 28 patients from peppering group accomplished the 12 week follow-up period. (Figure 1) The demographic characteristics of the patients 


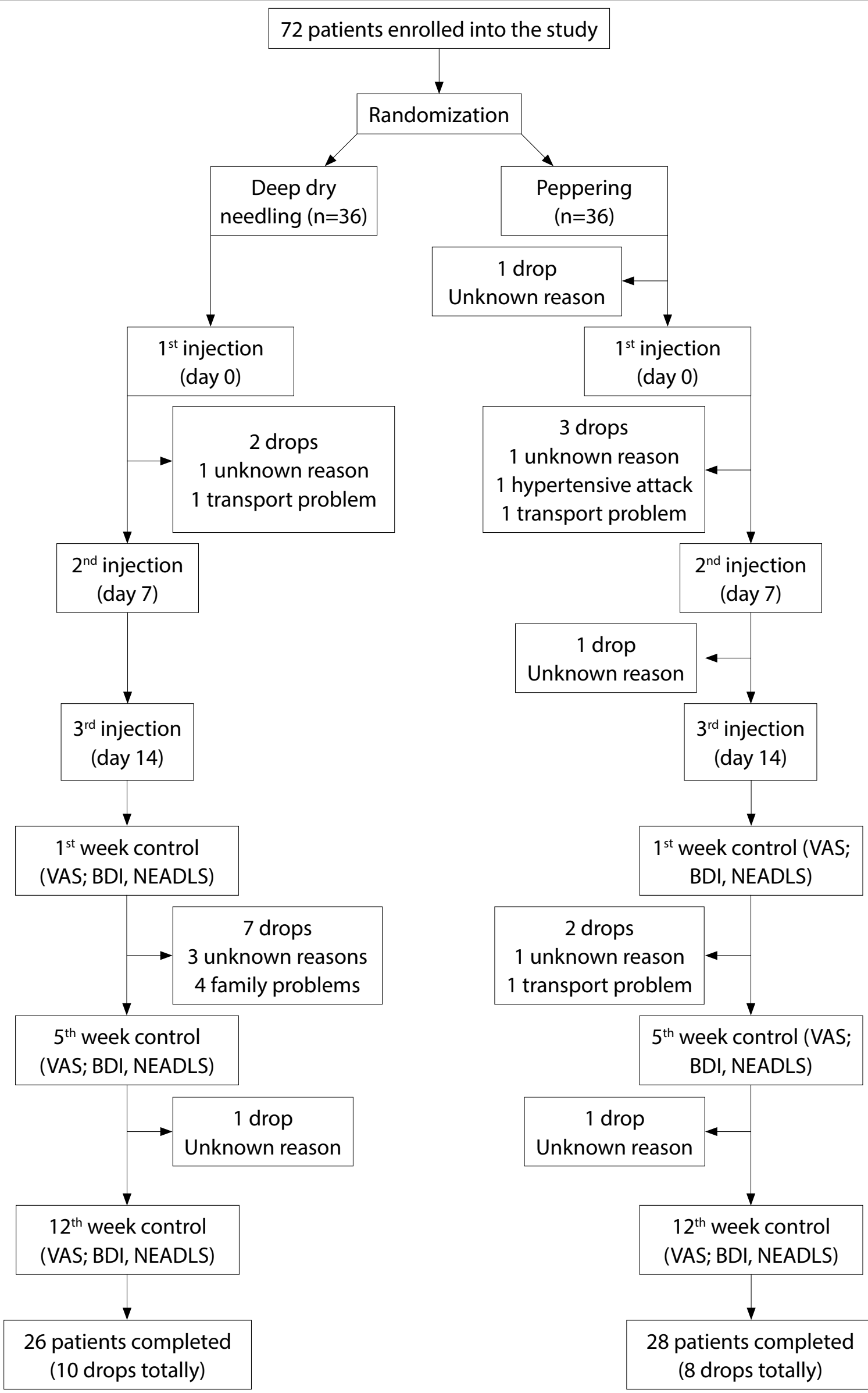

Figure 1. Flow chart of the study. 
Table 1. The demographic characteristics of the groups and the number of points needled

\begin{tabular}{|c|c|c|c|c|c|}
\hline & \multicolumn{2}{|c|}{$\begin{array}{l}\text { DDN group } \\
(n=26)\end{array}$} & \multicolumn{2}{|c|}{$\begin{array}{l}\text { Peppering group } \\
\qquad(n=28)\end{array}$} & \multirow[t]{2}{*}{$\mathbf{p}$} \\
\hline & $\mathbf{n}$ & $\%$ & $\mathbf{n}$ & $\%$ & \\
\hline Age & \multicolumn{2}{|c|}{$38.57 \pm 12.93$} & \multicolumn{2}{|c|}{$41.25 \pm 11.3$} & 0.06 \\
\hline \multicolumn{6}{|l|}{ Sex } \\
\hline Female & 21 & 80.77 & 25 & 89.29 & 0.37 \\
\hline Male & 5 & 19.23 & 3 & 10.71 & \\
\hline \multicolumn{6}{|l|}{ Socio-cultural level } \\
\hline Low & 7 & 26.92 & 11 & 39.28 & 0.33 \\
\hline High & 19 & 73.08 & 17 & 60.82 & \\
\hline \multicolumn{6}{|l|}{ Occupation } \\
\hline Active working/student & 16 & 61.54 & 12 & 42.86 & 0.17 \\
\hline Not active working & 10 & 38.46 & 16 & 57.14 & \\
\hline \multicolumn{6}{|l|}{ Marital status } \\
\hline Married & 16 & 61.54 & 18 & 64.29 & 0.83 \\
\hline Widowed/divorced & 10 & 38.46 & 10 & 35.71 & \\
\hline Total number of points needled (per 1 patient) & \multicolumn{2}{|c|}{$25.96 \pm 8.77$} & \multicolumn{2}{|c|}{$22.85 \pm 7.67$} & 0.17 \\
\hline
\end{tabular}

DDN: Deep dry needling.

and the number of points needled in both groups are summarized on Table 1. Trigger point distribution is presented on Figure 2. Pretreatment daytime and night VAS, BDI and NEADLS scores of the groups were similar (Table 2). Both DDN and peppering seem to be effective for relieving pain and depressive symptoms and improving functionality compared to baseline when evaluated on the $1^{\text {st }}, 5^{\text {th }}$ and $12^{\text {th }}$ weeks after the completion of the therapy, except $5^{\text {th }}$ week NEADLS results of the DDN group (Table 3). On the other hand the intergroup analyses showed no statistically significant differences between DDN and peppering groups in any of the above mentioned scales (Table 4) or adverse event profiles (Table 5). The only statistically significant difference between the groups is the lesser pain felt during the procedure in the DDN group (Table 5).

\section{Discussion}

According to our results, DDN and peppering are both effective in improving pain, activities of daily living and depressive mood compared to baseline, and this effect proceeded over the course of 12 weeks. There is no statistically significant difference between the groups. The adverse event profile of both treatment forms are similar too. DDN method is

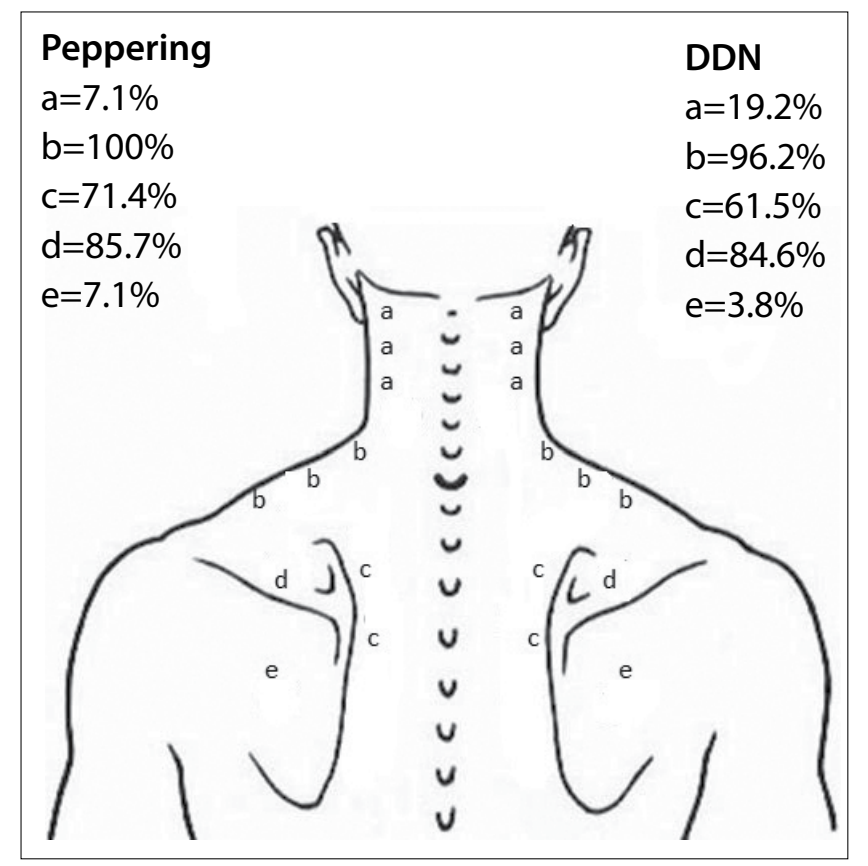

Figure 2. Trigger point distribution.

less painful for the patients, and this is the only statistically important difference between the groups.

In the literature, there is some evidence that both of these treatment modalities are effective in MPS. In a study by Tekin et al. the immediate effects of DDN on pain and quality of life was compared with that of 
Table 2. Comparison of pre-treatment daytime and night VAS, BDI and NEADLS scores between the groups

\begin{tabular}{lccc}
\hline & DDN group & Peppering group & p \\
\hline Pre-treatment daytime VAS & $67.81 \pm 19.28$ & $62.35 \pm 22.26$ & 0.34 \\
Pre-treatment night VAS & $47.00 \pm 25.79$ & $47.35 \pm 27.11$ & 0.96 \\
Pre-treatment BDI & $10.42 \pm 8.60$ & $12.57 \pm 9.37$ & 0.38 \\
Pre-treatment NEADLS & $56.80 \pm 7.52$ & $56.64 \pm 7.16$ & 0.93 \\
\hline
\end{tabular}

VAS: Visual analogue scale; BDI: Beck depression inventory; NEADLS: Nottingham extended activities of daily living scale; DDN: Deep dry needling.

Table 3. Treatment efficacy of the groups on $1^{\text {st }}, 5^{\text {th }}$ and $12^{\text {th }}$ weeks

\begin{tabular}{|c|c|c|c|c|c|c|c|}
\hline & Pt & ${ }^{1 s t}$ week & $\mathbf{p}^{1}$ & $5^{\text {th }}$ week & $\mathbf{p}^{2}$ & $12^{\text {th }}$ week & $\mathbf{p}^{3}$ \\
\hline & \multicolumn{7}{|c|}{ DDN group } \\
\hline Daytime VAS & $67.81 \pm 19.28$ & $24.65 \pm 17.12$ & $<0.001$ & $28.38 \pm 27.07$ & $<0.001$ & $24.30 \pm 20.22$ & $<0.001$ \\
\hline Night VAS & $47.00 \pm 25.79$ & $18.30 \pm 16.59$ & $<0.001$ & $20.38 \pm 17.50$ & $<0.001$ & $14.92 \pm 9.11$ & $<0.001$ \\
\hline BDI & $10.42 \pm 8.60$ & $6.15 \pm 4.57$ & $<0.001$ & $5.23 \pm 4.53$ & 0.018 & $3.92 \pm 4.71$ & $<0.001$ \\
\hline \multirow[t]{2}{*}{ Nottingham } & $56.80 \pm 7.52$ & $61.73 \pm 3.38$ & $<0.001$ & $60.50 \pm 11.87$ & 0.19 & $62.61 \pm 3.35$ & $<0.001$ \\
\hline & \multicolumn{7}{|c|}{ Peppering group } \\
\hline Daytime VAS & $62.35 \pm 22.26$ & $23.39 \pm 17.11$ & $<0.001$ & $19.32 \pm 17.4$ & $<0.001$ & $30.25 \pm 28.34$ & $<0.001$ \\
\hline Night VAS & $47.35 \pm 27.11$ & $14.25 \pm 11.96$ & $<0.001$ & $14.03 \pm 10.49$ & $<0.001$ & $22.57 \pm 19.45$ & $<0.001$ \\
\hline BDI & $12.57 \pm 9.37$ & $7.96 \pm 6.95$ & $<0.001$ & $8.67 \pm 6.61$ & $<0.001$ & $8.42 \pm 5.15$ & $<0.001$ \\
\hline Nottingham & $56.64 \pm 7.16$ & $61.46 \pm 4.38$ & $<0.001$ & $61.96 \pm 3.86$ & $<0.001$ & $61.32 \pm 5.29$ & $<0.001$ \\
\hline
\end{tabular}

Pt: Pre-treatment; P1: P of pre-treatment- $1^{\text {st }}$ week comparison; P2: P of pre-treatment- $5^{\text {th }}$ week comparison; $\mathrm{P}$ : $\mathrm{P}$ of pre-treatment- $12^{\text {th }}$ week comparison; DDN: Deep dry needling; VAS: Visual analogue scale; BDI: Beck depression inventory.

Table 4. The comparison of treatment efficacy between the groups on the $1^{\text {st }}, 5^{\text {th }}$ and $12^{\text {th }}$ week controls

\begin{tabular}{lccr}
\hline & DDN group & Peppering group & p \\
\hline $1^{\text {st }}$ week control & & & \\
$\Delta$ Daytime VAS & $38.96 \pm 22.43$ & $43.15 \pm 17.87$ & 0.45 \\
$\Delta$ Night VAS & $33.10 \pm 26.10$ & $28.69 \pm 24.95$ & 0.53 \\
$\Delta$ BDI & $4.60 \pm 3.99$ & $4.26 \pm 4.02$ & 0.75 \\
$\Delta$ NEADLS & $4.8 \pm 4.95$ & $4.92 \pm 5.54$ & 0.94 \\
$5^{\text {th }}$ week control & & & \\
$\Delta$ Daytime VAS & $43.03 \pm 21.01$ & $39.42 \pm 27.63$ & 0.58 \\
$\Delta$ Night VAS & $33.32 \pm 30.01$ & $26.61 \pm 30.1$ & 0.41 \\
$\Delta$ BDI & $3.89 \pm 5.16$ & $5.19 \pm 10.45$ & 0.56 \\
$\Delta$ NEADLS & $5.32 \pm 5.41$ & $3.69 \pm 14.05$ & 0.57 \\
$12^{\text {th }}$ week control & & & 0.14 \\
$\Delta$ Daytime VAS & $32.10 \pm 27.80$ & $43.50 \pm 28.29$ & 0.40 \\
$\Delta$ Night VAS & $24.78 \pm 36.57$ & $32.07 \pm 24.94$ & 0.21 \\
$\Delta$ BDI & $4.14 \pm 5.36$ & $6.50 \pm 8.22$ & 0.49 \\
$\Delta$ NEADLS & $4.67 \pm 4.40$ & $5.80 \pm 7.40$ &
\end{tabular}

$\triangle$ Daytime VAS: Difference between the pre-treatment daytime VAS and mentioned week daytime VAS; Night VAS: Difference between the pre-treatment night VAS and mentioned week night VAS; BDI: Difference between the pre-treatment BDI and mentioned week BDI; $\triangle \mathrm{NEADLS}$ : Difference between the pre-treatment NEADLS and mentioned week NEADLS. DDN: Deep dry needling; VAS: Visual analogue scale; BDI: Beck depression inventory; NEADLS: Nottingham extended activities of daily living scale. 
Table 5. The comparison of adverse event profile and the pain felt during the procedure

\begin{tabular}{lccc}
\hline & DDN group $(\mathbf{n = 2 6 )}$ & Peppering group $(\mathbf{n = 2 8})$ & p \\
\hline Adverse event & $13 / 26$ & $18 / 28$ & 0.28 \\
Pain-burning sensation & $11 / 26$ & $17 / 28$ & 0.17 \\
Nausea & $2 / 26$ & $3 / 28$ & 0.70 \\
Dizziness & $3 / 26$ & $5 / 28$ & 0.51 \\
Pain felt during the procedure & $52.88 \pm 21.86$ & $67.57 \pm 20.53$ & $\mathbf{0 . 0 1}$ \\
\hline
\end{tabular}

DDN: Deep dry needling.

sham dry needling in 39 patients and DDN was found superior to sham dry needling..$^{[9]}$ Likewise Itoh et al observed that DDN is more effective than traditional acupuncture and superficial dry needling, for pain relief and neck disability in 40 patients and these effects lasted for 12 weeks. ${ }^{[8]}$ On the other hand Hsieh et al. used $25 \mathrm{G}$ hypodermic needles for dry needling (peppering technique) in 14 MPS patients, and peppering was found effective for reducing pain and improving range of motion immediateley after the procedure. ${ }^{[17]}$ Hong et al. also used the peppering technique but assessed only the immediate effects in their study too. ${ }^{[12]}$ In another study demonstrating peppering technique is as effective as lidocain injection, 80 patients were evaluated on $4^{\text {th }}$ and $12^{\text {th }}$ week after the procedures, but the effect of the treatments within the first month is unknown. ${ }^{[13]}$

Altough the above mentioned literatures all support the efficacy of dry needling in MPS, the needling techniques, and the needles used are not well defined and standardized. In this study we aimed to standardize, define and compare directly the two dry needling techniques disparate in origin. The patients were evaluated on $1^{\text {st }}, 5^{\text {th }}$ and $12^{\text {th }}$ weeks after the completion of the procedures for immediate, medium and late term effects of the treatments and not only the pain but also the depressive status and activities of daily living were evaluated. Besides, in MPS the effect of dry needling on the activities of daily living is investigated for the first time in the literature.

Furthermore the side effect profiles of the two dry needling techniques were also evaluated. The most common ones are pain, nausea and dizziness on the day of the injection. Sometimes these effects may continue on the first few days. There has been one hypertensive attack in the peppering group. This case was a 45 year old woman who was on combi- nation therapy of perindopril $5 \mathrm{mg}$ and indapamide $1.25 \mathrm{mg}$ for hypertension. She was represented with serious headache and diagnosed as hypertensive attack at the emergency service after the first injection. After then she was excluded from the study.

\section{Limitations}

Further studies with a larger number of patients should be performed to evaluate the effects more accurately. Moreover there is not a real control group in this study and this is also a limitation. The fact that neither the patients, nor the physicians were blind make it harder to interprete the results.

\section{Coclusions}

In conclusion both DDN and peppering appear to be effective in alleviating pain and depressive symptoms and improving ADL in MPS and these effects start immediately after the procedures and last up to 12 weeks. Also the adverse event profile of the two techniques are similar too. On the other hand, DDN is a more painless procedure and may be the preferred technique because of this reason.

\section{Conflict-of-interest issues regarding the authorship or article: None declared.}

Peer-rewiew: Externally peer-reviewed.

\section{References}

1. Graff-Radford SB. Myofascial pain: diagnosis and management. Curr Pain Headache Rep 2004;8(6):463-67.

2. Ge HY, Wang Y, Danneskiold-Samsøe B, Graven-Nielsen $T$, Arendt-Nielsen $L$. The predetermined sites of examination for tender points in fibromyalgia syndrome are frequently associated with myofascial trigger points. J Pain 2010;11(7):644-51.

3. Kietrys DM, Palombaro KM, Azzaretto E, Hubler R, Schaller $B$, Schlussel JM, et al. Effectiveness of dry needling for upper-quarter myofascial pain: a systematic review and me- 
ta-analysis. J Orthop Sports Phys Ther 2013;43(9):620-34.

4. Gerwin RD. A review of myofascial pain and fibromyalgia-factors that promote their persistence. Acupunct Med 2005;23(3):121-34.

5. Rayegani SM, Bayat M, Bahrami MH, Raeissadat SA, Kargozar E. Comparison of dry needling and physiotherapy in treatment of myofascial pain syndrome. Clin Rheumatol 2014;33(6):859-64.

6. Gunn CC, Milbrandt WE, Little AS, Mason KE. Dry needling of muscle motor points for chronic low-back pain: a randomized clinical trial with long-term follow-up. Spine (Phila Pa 1976) 1980;5(3):279-91.

7. Irnich D, Behrens N, Gleditsch JM, Stör W, Schreiber MA, Schöps $P$, et al. Immediate effects of dry needling and acupuncture at distant points in chronic neck pain: results of a randomized, double-blind, sham-controlled crossover trial. Pain 2002;99(1-2):83-9.

8. Itoh K, Katsumi Y, Hirota S, Kitakoji H. Randomised trial of trigger point acupuncture compared with other acupuncture for treatment of chronic neck pain. Complement Ther Med 2007;15(3):172-9.

9. Tekin L, Akarsu S, Durmuş O, Cakar E, Dinçer U, Kıralp MZ. The effect of dry needling in the treatment of myofascial pain syndrome: a randomized double-blinded placebocontrolled trial. Clin Rheumatol 2013;32(3):309-15.
10. Simons DG, Travell JG, Simons LS. Travell and Simons' Myofascial Pain and Dysfunction: The Trigger Point Manual. Vol 1. $2^{\text {nd }}$ ed. Baltimore, MD: Williams \& Wilkins 1999.

11. Lewit $\mathrm{K}$. The needle effect in the relief of myofascial pain. Pain 1979;6(1):83-90.

12. Hong CZ. Lidocaine injection versus dry needling to myofascial trigger point. The importance of the local twitch response. Am J Phys Med Rehabil 1994;73(4):256-63.

13. Ay S, Evcik D, Tur BS. Comparison of injection methods in myofascial pain syndrome: a randomized controlled trial. Clin Rheumatol 2010;29(1):19-23.

14. Dunning J, Butts R, Mourad F, Young I, Flannagan S, Perreault $\mathrm{T}$. Dry needling: a literature review with implications for clinical practice guidelines. Phys Ther Rev 2014;19(4):252-65.

15. Sahin F, Yilmaz F, Ozmaden A, Kotevoglu N, Sahin T, Kuran B. Reliability and validity of the Turkish version of the Nottingham Extended Activities of Daily Living Scale. Aging Clin Exp Res 2008;20(5):400-5.

16. Hisli M. Beck Depresyon Envanterinin psikiyatri hastaları için geçerliliği. Psikoloji Dergisi 1988;21:118-26.

17. Hsieh YL, Kao MJ, Kuan TS, Chen SM, Chen JT, Hong CZ. Dry needling to a key myofascial trigger point may reduce the irritability of satellite MTrPs. Am J Phys Med Rehabil 2007;86(5):397-403. 